\title{
Getting Voluntary Patriotic Practices Integrated in Poverty Reduction Policy Frameworks
}

\author{
Ayoub Mohammed Mahmoud* \\ Open University of Tanzania-Zanzibar Centre, Tanzania \\ *Corresponding author: Ayoub Mohammed Mahmoud, Open University of Tanzania-Zanzibar Centre, Tanzania
}

\section{Introduction}

The widely revealed roles and contributions of voluntary patriotic practices on poverty reduction in Zanzibar [1], calls for a rationale for enhancing the practical usefulness of voluntary patriotic practices on poverty reduction initiatives in Zanzibar. This is mainly envisaged the need of integrating the practically tested voluntary patriotic practices in the poverty reduction policy frameworks. The tested result-based voluntary patriotic practices in various areas of Zanzibar seem to be useful in the course of enhancing prevailing poverty reduction initiatives under various Zanzibar Poverty Reduction policy frameworks and other socioeconomic development related strategies. While the voluntary patriotic practices have shown some promising results in some countries in one hand, on the other hand it doesn't make much difference in other countries since they are left behind in the development processes and other related poverty reduction policy frameworks. According to UNDP [2] poverty reduction has been a common agenda for almost every government in the world such that many governments in developing countries including Zanzibar. The need of posing serious attention to voluntary patriotic practices is due to inadequate resources problem which is always experienced by these countries and which usually makes the countries seek solutions to eradicate poverty at international levels instead of strengthening their initiatives in their internal strengths' capacities including the use of available people in the local levels.

The challenges, usefulness and roles of voluntary patriotic practices towards nation building initiatives and community social and economic development activities are widely posited [1-8] while leaving behind the rationale of integrating the practically tested voluntary patriotic practices in the countries poverty reduction policy frameworks. The roles of voluntary patriotic practices in the poverty reduction initiatives are undoubtedly and quite widely known including their ability to save and enhance majority of resource-intensive initiatives by replacing the workforce contributed by voluntary practices ranging from voluntary financial contribution, voluntary material contribution, voluntary manpower contribution, voluntary service provision, participatory community projects planning, voluntary community support, voluntary cleaning activities, participatory security patrols and voluntary whistle-blowing for public resources management [1]. Back to Zanzibar context, the recently revealed voluntary patriotic practices have been widely applied back in 1960s by the then Revolutionary Government of Zanzibar under the leadership of the first President late Sheikh Abeid Aman Karume who had successfully practiced numerous voluntary patriotic practices.

The practices including building communal settlements, schools, hospitals and health centres in various areas of Zanzibar, were mainly done by voluntary mobilized workforce from the members of communities also voluntary material and financial contributions. According to MKUZA [9], The Revolutionary Government of Zanzibar (RGoZ) has consistently aspired to improve the welfare of her people mainly through increasing income, eradicating diseases and fighting ignorance as contained in the Vision 2020 and Millennium Development Goals (MDGs) and the recently Sustainable Development Goals. In 2000, the Government adopted the Zanzibar Development Vision 2020. The Zanzibar Development Vision 2020 is a long-term development framework which charts out what Zanzibar aspires to be by the year 2020. The vision, outlines in broad terms, the economic, social and political aspirations of Zanzibar to guide future policies, strategies and plans. Furthermore, the RGoZ has committed itself to the pursuance and the attainment of the (MDGs) by the year 2015 in order to improve the wellbeing of the people of Zanzibar. The adopted policies have been using various development models including direct government financing which result to unsustainable outcomes as the government capacity to finance fall short. This among 
other things have made the government to look for other useful mechanisms in the course of supporting the existing initiatives in due course of poverty reduction initiatives which stand as chronic problem to majority of developing countries including Zanzibar.

The introduction of voluntary patriotic practices in various poverty reduction initiatives could be treated as the new resultbased socio-economic development model for developing countries such that the manipulation of its outcomes could be of high usefulness. In the quest for an alternative development model that is affordable, inclusive, responsive, humanising, equitable and environmentally sustainable, a people-centered development with high level of patriotic attitude and people's voluntary participation has been recognised as a new development paradigm today [4-6]. The Non-Governmental Organisations and Non-State Actors with their participatory approach, people's mobilising capacity, closeness to grass roots local communities and better insights into the needs of the people have recently emerged as alternative development model in the many areas of modern Zanzibar, particularly in Urban West region. The voluntary patriotic practices have highly evolved as a viable community development strategy. It is a matter of fact that voluntarism spirit in the various areas of Zanzibar has gained momentum with the advancement of the society from time to time.

However, in the current times, the role of voluntarism which is mostly pioneered by civil societies and some government structures; has been widely recognized as indispensable in the process of development $[2,3]$. The increasingly practiced voluntary patriotic practices stand as newly adopted paradigm of community development are envisaged as a the most effectives peoplecentered development with has been widely recognized as a new paradigm today socio-economic development $[1,2,7,9]$. Following the recent developments in the applications of voluntary patriotic practices on poverty reduction in Zanzibar [1], the usefulness and significance of integrating voluntary patriotic practices on poverty reduction initiatives in Zanzibar require more attachment into legal and administrative systems, structures and institutions for smooth implementation of socio-economic development processes. The tested result-based voluntary patriotic practices in various areas of Zanzibar have been proved to be successful in the course of enhancing poverty reduction initiatives prevailing in Zanzibar hence calling for a serious integration of practically tested voluntary patriotic practices in Zanzibar Poverty Reduction policy frameworks and other development related strategies. This Mini-Review stresses the need of mainstreaming the evidenced voluntary patriotic practices in various poverty reduction policy frameworks for sustainable undertaking of various socio-economic development processes in various developing countries.

\section{References}

1. Mahmoud AM (2018) The role of voluntary patriotic practices on poverty reduction initiatives in Zanzibar: A case of West B District in Urban West Region, Zanzibar. Unpublished Master Thesis from Open University of Tanzania.

2. United Nations Development Programme (2015) Human Development Report; Work for Human Development New York, USA.

3. Odhiambo NM (2009) Savings and Economic Growth in South Africa: A Multivariate Causality Test. Journal of Policy Modeling 31(5): 708-718.

4. Aikaeli J (2010) Determinants of Rural Income in Tanzania: An Empirical Approach Research Report 10/4, Dar es Salaam, REPOA.

5. Simbila GK (2011) Challenges in Measuring Poverty in Tanzania: National Bureau of Statistics (Tanzania).

6. United Republic of Tanzania (2014) National Population Census 2012. National Bureau of Statistics, Ministry of Finance, Dar es Salaam, Tanzania.

7. Adejumo A (2014) Benjamin Adekunle Black Scorpion is Dead. Elombah, A Nigeria Perspective on the World Affairs.com.

8. Negedu I (2015) Nationalism in Nigeria: A Case for Patriotic Citizenship. American International Journal of Contemporary Research 5(3): 74.

9. Mkuza (2012) Zanzibar Strategy for Growth and Reduction of Poverty (ZSGRP II). The Revolutionary Government of Zanzibar. Zanzibar Government Press.
This work is licensed under Creative Commons Attribution 4.0 License

To Submit Your Article Click Here: Submit Article

DOI: $10.32474 /$ CIACR.2019.06.000227

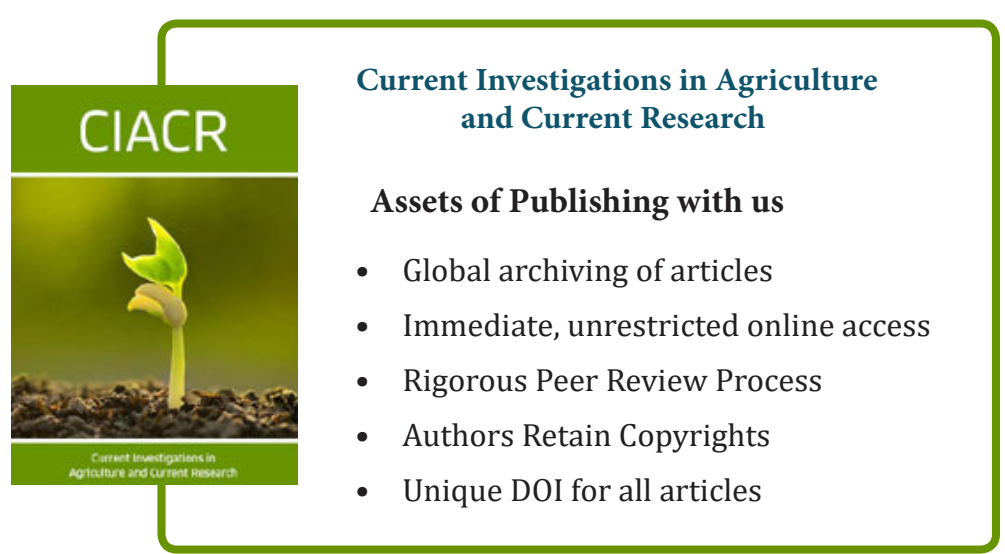

